\title{
The effect of perceived organizational support and psychological capital on OCB: mediating role of engagement
}

\author{
Muhammad Ali Ansori ${ }^{1}$ and Nury Ariani Wulansari ${ }^{1}$ \\ ${ }^{1}$ Department of Management, Faculty of Economics, Universitas Negeri Semarang, Indonesia
}

\begin{abstract}
This paper aims to investigate the effect of psychological capital (PsyCap) as an intrinsic factor and perceived organizational support (POS) as an extrinsic factor on OCB and to verify the mediating role of work engagement (WE) in the relationship of PsyCap, POS and OCB. The population in this study are state university lecturers especially at Universitas Negeri Semarang. Using proportionate random sampling technique, the data was collected from 145 lecturers. The structural equation model-partial least square (SEM-PLS) was used to test the hypotheses with analysis tools in the form of SmartPLS 3.0. The result showed that PsyCap had a positive and significant effect on work engagement and OCB, then POS had an insignificant effect on OCB and work engagement. The result found that work engagement has a mediation effect in the relationship between PsyCap and OCB. This study also showed that PsyCap as an intrinsic factor is considered more capable than POS as an extrinsic factor to improve lecturer's OCB. It is highly recommended for the organization to focus on lecturer's psychological capital investment, because lecturer's PsyCap will be directly affect to lecturer's positive behaviour such as work engagement and OCB.
\end{abstract}

\section{INTRODUCTION}

Organization goals can only be achieved if the organization pays attention to employees' behavior in the workplace. Previous study by Basu et al. (2017) explained that one of positive behaviors which significantly affect employee performance is OCB. Organ, (1997) defined OCB as an employee's discretionary workrelated activity that are carried out outside of their job description and in the aggregate may help the organization in achieving its main goals. Extra-role behavior such as OCB is very important in the organization (Hall \& Ferris, 2011). Employees behavior is considered to have an effect on organizational progress and organizational survival. Park, (2019) explains that beside to employee's in-role behavior, it is also necessary to encourage employee extrarole behavior such as OCB to increase the effectiveness of an organization. Furthermore, Perreira \& Berta, (2015) explained that OCB is considered very important for organizations because it greatly contributes to the efficient use of company resource which are limited, so that will increase organizational productivity.

The implication of OCB can't be directly embedded in each employee, but it can be formed through the influence of certain factors. The first factor that's indicated to have an effect on OCB is organizational support (Sánchez \& Pasamar, 2020). Practically, organizational support provided to employees can be realized by providing fairness salaries and reward, recognition by the company, job promotion and job stability (Burmeister \& Deller, 2016). Based on organizational support theory, the previous study by Tan et al. (2019) explains that employees will be more active when they feel that the organization is willing to provide support them. Therefore, if the organization wants to create an optimal work culture in the workplace, it's important for the organization to always provide various support to its employees (Sia \& Duari, 2018).

The another factor that also indicated to have an effect on OCB but tendes to be rarely studied is psychological capital (PsyCap) (Wu \& Nguyen, 2019). Previous organizational behavior research argues that the employee's psychological conditions 
will be directly proportional to their attitude and behavior (Rego et al. 2016). It could be interpreted that if an employee has a positive psychological condition, then they will tend to behave positively at work and vice versa. Newman, et. al., (2014) explains that the employee's PsyCap is one of the important variables that was contributed to stimulate individual organizational performance and positive behavior in the workplace. Employees with high PsyCap have effectivity and resilience to any work challenges and always confident in their work result (Gupta et al. 2017). Furthermore, when employees with positive PsyCap are satisfied with their recording jobs, then they will actively help their coworker or supervisor and show integrity to organization (Hyo \& Hye, 2015).

Previous studies that tested relationship between perceived organizational support (POS), PsyCap and OCB have been conducted several times, but there are still found some research gap, specifically in the test of direct effect between predictors and consequences. For example previous study by Jehanzeb, (2020) has shown that POS has no effect on OCB and study by Bogler \& Somech, (2019) which show that PsyCap has no effect on OCB.

Previous studies by Shams et al. (2020) and Gupta et al. (2017) found that there is another variable involved in the relationship between POS, PsyCap and OCB, namely work engagement. Kahn, (1997) defines work engagement as self-empowerment of organizational members in their roles, by expressing themselves physically, cognitively and emotionally in work. In addition, work engagement is also considered a proximal construction that reflects their work context, which in turn will act as a bridge that connects organizational resources with relevant organizational behaviors such as OCB (Kataria et al. 2019). Therefore, this study aims to re-examine the mediating role of work engagement on the relationship between POS, PsyCap and OCB to generalize the results of previous studies by testing on objects from different sectors and country.

This study focuses on lecturers at universities. We choose lecturer as a sample of our study because they are human resources with a very central role in all activities and have a role in the character building of students. Moreover, with the main principles of the "Tri Dharma Perguruan
Tinggi", a lecturer is always required to carry out multiple roles in their work environment. Some of these multiple roles include teaching, conducting research, and providing guidance to students who are conducting research (O'Laughlin \& Bischoff, 2005).

This is one of the reasons for the importance of instilling OCB in lecturers. Because OCB embedded in lecturers will stimulate lecturers to further improve their performance (Huei et al. 2014). It can be assumed that if OCB is embedded in lecturers, it is likely that they will help each other in their work and this will increase the chances of lecturers in achieving their employee performance targets. When the level of performance achieved is high, it will affect to the agency's performance appraisal and become a supporting indicator in terms of ranking universities in Indonesia.

Based on the introduction, this study aims to investigate the effect of psychological capital (PsyCap) as an intrinsic factor and perceived organizational support (POS) as an extrinsic factor on lecturer's $O C B$ and to verivy the mediating role of work engagement (WE) in the relationship of PsyCap, POS and OCB. This study also aims to examine which factors are considered more capable of influencing lecturers' OCB, whether PsyCap as an intrinsic factor or POS as an extrinsic factor.

\section{LITERATURE REVIEW AND HYPOTHESES DEVELOPMENT}

\section{Perceived organizational support and OCB}

Employees' perceived organizational support became the important factors that influence the formation of employee attitudes and behavior (Liu \& Liu, 2021). A positive POS will lead employees to work better, that showed by helping the organization to achieve its goals and objectives, as well as directing employees to a positive mood and psychological (Kurtessis et al. 2017). This perception refers to how much organizations value their various contributions and the extent to which organizations care about their socioemotional needs (Eisenberger et al. 1986).

Social Exchange Theory (SET) argues that in fact, all interactions between humans rely on a give and take scheme (Gouldner, 1960). Based on SET, when employees 
perceive that the organization has provided more support to them, they will give a return to the company (Liu \& Liu, 2021). One of them is by showing discretionary behavior in the workplace (Frenkel \& Bednall, 2016) and being willing to work for the organization, even though it is outside of their duties and obligations (Ahmed \& Nawaz, 2015).

H1: POS has positive and significant effect on lecturers $O C B$

\section{Psychological capital and OCB}

Capital is the primary factor for organizations in carrying out their various operational activities, both economic capital and social (Pradhan et al. 2016). However Seligman, (2002) explains that there is a fourth need for capital, called psychological capital (Psycap). Based on broaden and build theory, Fredrickson, (2003) Explains that employees with broad thinking will be more potential to engage in various extra-role behaviors.

Previous research by (Gupta et al. 2017) proves that employees with high PsyCap are considered full of resilience to challenges and confident in their work results. Furthermore, when employees with positive PsyCap are satisfied with their recording jobs, then they will actively help their coworker or supervisor and show integrity to organization (Jung \& Yoon, 2015). Previous research by Wu \& Nguyen, (2019) also proved that employee PsyCap will have a positive and significant effect on work attitudes such as job satisfaction, commitment and OCB.:

H2: PsyCap has positive and significant effect on lecturers $O C B$

\section{Perceived organizational support and work engagement}

Organizational support theory argues that when employees perceived that the organization has provided sufficient support for them, it will stimulate employees to be more engaged on their job (Tan et al. 2019). The support provided by the organization will stimulate mental and psychological employees to serve the organization (Ahmed \& Nawaz, 2015), which is realized through positive attitudes and behavior development that benefical the organization, which leads to a form of high work engagement by employees.

Several previous studies have also proven that POS has a significant effect on work engagement, for example Liu et al. (2017) which proves that POS is able to increase work engagement and Musenze et al. (2020) POS is positively and significantly able to predict work engagement.

H3: POS has positive and significant effect on lecturers work engagement

\section{Psychological capital and work engagement}

The concept of psychological capital refers to employees level of self-efficacy, hope, optimism and resilience (Luthans et al. 2007). Employees with high psychological capital and have structured goals will be easily motivated intrinsically (Joo \& Lee, 2017). This is because employees with high psychological capital always see things from a positive perspective, have good problemsolving skills and always move forward when faced with challenging situations (Kang \& Busser, 2018). So that cognitively, emotionally and physically will be involved in their work (Joo \& Lee, 2017).

Several previous studies have also proven that psychological capital has a significant effect on work engagement, for example Alessandri et al. (2018) which proves that psychological capital has a positive and significant effect on work engagement and $\mathrm{Xu}$ et al. (2017) which proves that leadership's psychological capital has a positive effect. and significant at the level of work engagement.

H4: PsyCap has positive and significant effect on Lecturers work engagement

\section{Work engagement and OCB}

The concept of work engagement refers to the positive behavior of an employees in their work, which is characterized by vigor, dedication and high absorption in work (Schaufeli et al. 2002). Just as organizations want to understand how they can make their employees dedicated to their work, in the same way employees who are committed to their work will also try to understand how they can make the organization excel (Srivastava \& Madan, 2016). This positive behavior is also considered to be able to 
stimulate employees to perform some positive discretionary behaviors such as OCB (Tufail et al. 2017).

Several previous studies have also proven that psychological capital has an effect on OCB, for example Prottas \& Nummelin, (2018) which explains that work engagement has a positive and significant effect on OCB and Yin, (2018) which proves that work engagement significantly affects OCB behavior of SME employees. Based on this context, the fifth hypothesis in this study is:

H5: Work engagement has positive and significant effect on $O C B$

\section{Mediating role of work engagement}

Several previous studies have proven that there is a direct relationship between POS, psychological capital and OCB (Ahmed \& Nawaz, 2015; Han et al. 2019; Jung \& Yoon, 2015; Wu \& Nguyen, 2019). However, it is still unknown how POS and psychological capital can increase OCB. Shams et al. (2020) in their research explain that when employees feel that their contributions are valued and their welfare is guaranteed by the organization, they will offer a positive attitude to the organization and increase their work role which will indirectly lead to OCB.

Further research by Gupta et al. (2017) found that, employees with good psychological capital will display discretionary work behavior in the organization but only when they are committed and engaged in their work. Based on this explanation, it is assumed that psychological capital indirectly affects OCB through employee work engagement.

Several previous studies have also proven that work engagement mediates the relationship between POS, psychological capital and OCB, for example, Shams et al. (2020) explain that work engagement mediates the relationship between POS and OCB in front-line employees. Gupta et al. (2017) prove that work engagement mediates the relationship between psychological capital and OCB. Based on this context, the sixth and seventh hypotheses in this study are:

H6: Work engagement mediates the relationship between POS and OCB
H7: Work engagement mediates the relationship between PsyCap and OCB

\section{METHODS}

\section{Procedure and sample}

The population in this study were lecturers of state universities at the Universitas Negeri Semarang located in Indonesia. The sample in this study was 145 respondents who were selected randomly with proportionate random sampling technique. The data collection method was carried out using an online questionnaire with a Likert scale of 1 5 . The data was processed and analyzed using the Structural Equation Model-Partial Least Square (SEM-PLS) method using the Smart PLS 3.0 program.

\section{Measurement}

\section{Perceived organizational support (POS)}

The POS variable was measured using six indicator items adopted from Eisenberger et al. (2001), using a Likert scale with a vulnerable scale of 1-5. Two sample item from the POS variable are "UNNES is proud of my achievements" and "UNNES really cares about my well-being".

\section{Psychological capital (PsyCap)}

PsyCap was measured using 12 item psychological capital questionnaire (PCQ12) adopted from Kim \& Beehr, (2019) which was shortened from a 24 item psychological capital questionnaire (PCQ-24) Luthans et al. (2007), using a Likert scale with a scale range of 1-5. One sample statement from the PsyCap variable are, "I am confident in the contribution I make to the development of the department in the future".

\section{Work engagement (WE)}

WE was measured using a five-item statement adopted from Park, (2019), using a Likert scale with a scale range of 1-5. One of the sample item statements from the WE variable are, "I feel energetic when teaching". 
Table 1.

Sample Demographic Characteristics

\begin{tabular}{llr}
\hline $\begin{array}{c}\text { Demographic } \\
\text { Variabel }\end{array}$ & \multicolumn{1}{c}{ Sample Composition } \\
\hline Gender & Male & $40 \%$ \\
& Female & $60 \%$ \\
Education & Magister & $67 \%$ \\
& Doctor & $33 \%$ \\
Years of service & $0-10$ Years & $38 \%$ \\
& $11-20$ & $33 \%$ \\
& Years & $23 \%$ \\
& $21-30$ & $6 \%$ \\
Ymployement & $>30$ Years & \\
Status & BLU & $6 \%$ \\
& Contract & $94 \%$ \\
\hline
\end{tabular}

\section{Organizational citizenship behavior (OCB)}

OCB was measured using eight statement items adopted from Lee \& Allen, (2002) shortened by Saks, (2006). Using a Likert scale with a range of 1-5, One sample statement item from the OCB variable are, "I often help other lecturers who have problems related to their work".

\section{RESULTS AND DISCUSSION}

\section{Data collection}

A total of 329 questionnaires were distributed online using whatsapp and e-mail messages, but only 210 questionaire were received. The number of samples used in this study was 145 . The sample consisted of $94 \%$ of lecturers with civil servant status and $6 \%$ with contract status, $61 \%$ sample are female and $39 \%$ male. In summary, the demographic characteristics of the respondents are presented in Table 1.

\section{Outer model}

The convergent validity test refers to the outer loadings value of each statement indicator. An indicator item is declared valid if it has an outer loadings value in accordance with the rule of thumb $>0.7$ (Hair et al. 2016) or has an AVE value > 0.5 (Abdillah \& Hartono, 2015). The results of the validity test indicate that there are several indicator items that have a value of outer loadings $<0.07$, namely, each of the three indicator items on the OCB variable $(3,4,7)$ and psychological capital $(5,7,8)$ so they must be eliminated. Furthermore, based on table 2, and looking at the rule of thumb it is known that each variable has AVE $>0.5$, therefore it can be interpreted that the data is valid and has good convergent validity.

Furthermore, the reliability test refers to the value of Cronbach alpha and composite reliability which are considered better in estimating the internal consistency of a construct. The rule of thumb reliability test set as $\alpha>0.7$ (Abdillah \& Hartono, 2015). The results of the reliability test are presented in table 2. The results show that the variables of POS, psychological capital, OCB and work engagement each have Cronbach alpha values of $0.855,0.850$, 0.832 and $0.872(>0.70)$ and composite reliability $0.891,0.888,0.880,0.907(>0.70)$. it can be interpreted that the instrument has

Table 2.

Convergent Validity and Reliability

\begin{tabular}{ccccc}
\hline Constructs & AVE & Composite Reliability & R square & Cronbach's Alpha \\
\hline Work Engagement & 0.662 & $\mathbf{0 . 9 0 7}$ & - & $\mathbf{0 . 8 7 2}$ \\
OCB & 0.596 & $\mathbf{0 . 8 8 0}$ & 0.256 & $\mathbf{0 . 8 3 2}$ \\
Psychological Capital & 0.569 & $\mathbf{0 . 8 8 8}$ & 0.178 & $\mathbf{0 . 8 5 0}$ \\
$\begin{array}{c}\text { Peerceived } \\
\text { Organizational Support }\end{array}$ & 0.579 & $\mathbf{0 . 8 9 1}$ & - & $\mathbf{0 . 8 5 5}$ \\
\hline
\end{tabular}


Table 3.

Predictive Relevance

\begin{tabular}{lccc}
\hline \multicolumn{1}{c}{ Variabel } & SSO & SSE & $\begin{array}{c}\mathbf{Q}^{2} \text { (=1- } \\
\text { SSE/SSO) }\end{array}$ \\
\hline Engagement & 725.000 & 650.584 & 0.103 \\
OCB & 1.160 .000 & 1.071 .052 & 0.077 \\
PsyCap & 1.305 .000 & 1.305 .000 & \\
POS & 870.000 & 870.000 & \\
\hline
\end{tabular}

the ability to produce measurements consistently.

\section{Inner model}

\section{Variant analysis $\left(R^{2}\right)$ and predictive relevance $\left(Q^{2}\right)$}

Analysis of variance $\left(R^{2}\right)$ is used to measure the level of variance of independent changes in the dependent variable, the higher value of $R^{2}$, indicated a higher prediction model of the proposed research model (Abdillah \& Hartono, 2015). The predictive-relevance value is obtained by the formula $\mathrm{Q}^{2}=1$ - (SSE/SSO) that presented in table 3 .

Based on table 2 shows that the value of $R^{2}$ work engagement variable is 0.178 and OCB 0.256 . It means that the coefficient determination of work engagement $17.8 \%$ can be explained by the variable POS and psychological capital, while the remaining $82.2 \%$ is explained by other variables outside the model in the study. Furthermore, the coefficient determination of OCB $25.6 \%$ can be explained by the variables of work engagement, POS and psychological capital while the remaining $74.4 \%$ is explained by other variables outside the research model. Table 3 shows the predictive relevance of the research model. The results show that the predictive relevance value for the endogenous variable of work engagement is 0.103 and OCB is 0.077 , this shows that $Q^{2}$ greater than zero $\left(Q^{2}>0\right)$. Hence, it can be interpreted that the model already has predictive relevance.

\section{Goodness of fit (GoF)}

Based on the calculation results, the GoF value is $0.3612(>0.36)$. Based on this, it can be interpreted that there is a match between the observations and the frequency obtained based on the expected value.

$$
\begin{aligned}
\text { GoF } & =\sqrt{A V E \times R^{2}} \\
& =\sqrt{0,601 \times 0,217} \\
& =\sqrt{0,1305} \\
& =0,3612
\end{aligned}
$$

\section{Hypotheses testing}

\section{Perceived organizational support and $O C B$}

Based on table 4, the results show that the original sample $(\beta)$ value is 0.129 and $t-$ statistic is $1.410<1.96$ with a significance value of $0.140>0.05$. Therefore, $\mathrm{H} 1$ is rejected. POS has an insignificat effect on lecturers OCB at Universitas Negeri Semarang.

Although previous research has shown that perceived organizational support has a positive and significant effect on organizational citizenship behavior, for example in the research of Han et al. (2019) dan Liu \& Liu, (2021). However, in the case of a sample of lecturers at Universitas Negeri Semarang, perceived organizational support isn't strongly in influencing the organizational citizenship behavior of lecturers. This is supported by previous research by Tan et al. (2019) which proves

Table 4.

Path Coefficient

\begin{tabular}{lcccccc}
\hline Hypotheses & \multicolumn{2}{c}{ Relationship } & $\begin{array}{c}\text { Original } \\
\text { Sample(O) }\end{array}$ & p-value & Description \\
\hline Hypotheses 1 & POS & $\rightarrow$ & OCB & 0.133 & $\mathbf{0 . 1 4 0}$ & Rejected \\
Hypotheses 2 & PsyCap $\rightarrow$ & SWB & 0.209 & $\mathbf{0 . 0 3 5}$ & Supported \\
Hypotheses 3 & POS $\rightarrow$ & WE & 0.000 & $\mathbf{0 . 9 9 7}$ & Rejected \\
Hypotheses 5 & PsyCap & $\rightarrow$ & WE & 0.421 & $\mathbf{0 . 0 0 0}$ & Supported \\
Hypotheses 6 & WE $\rightarrow$ & OCB & 0.211 & $\mathbf{0 . 0 1 7}$ & Supported \\
\hline
\end{tabular}




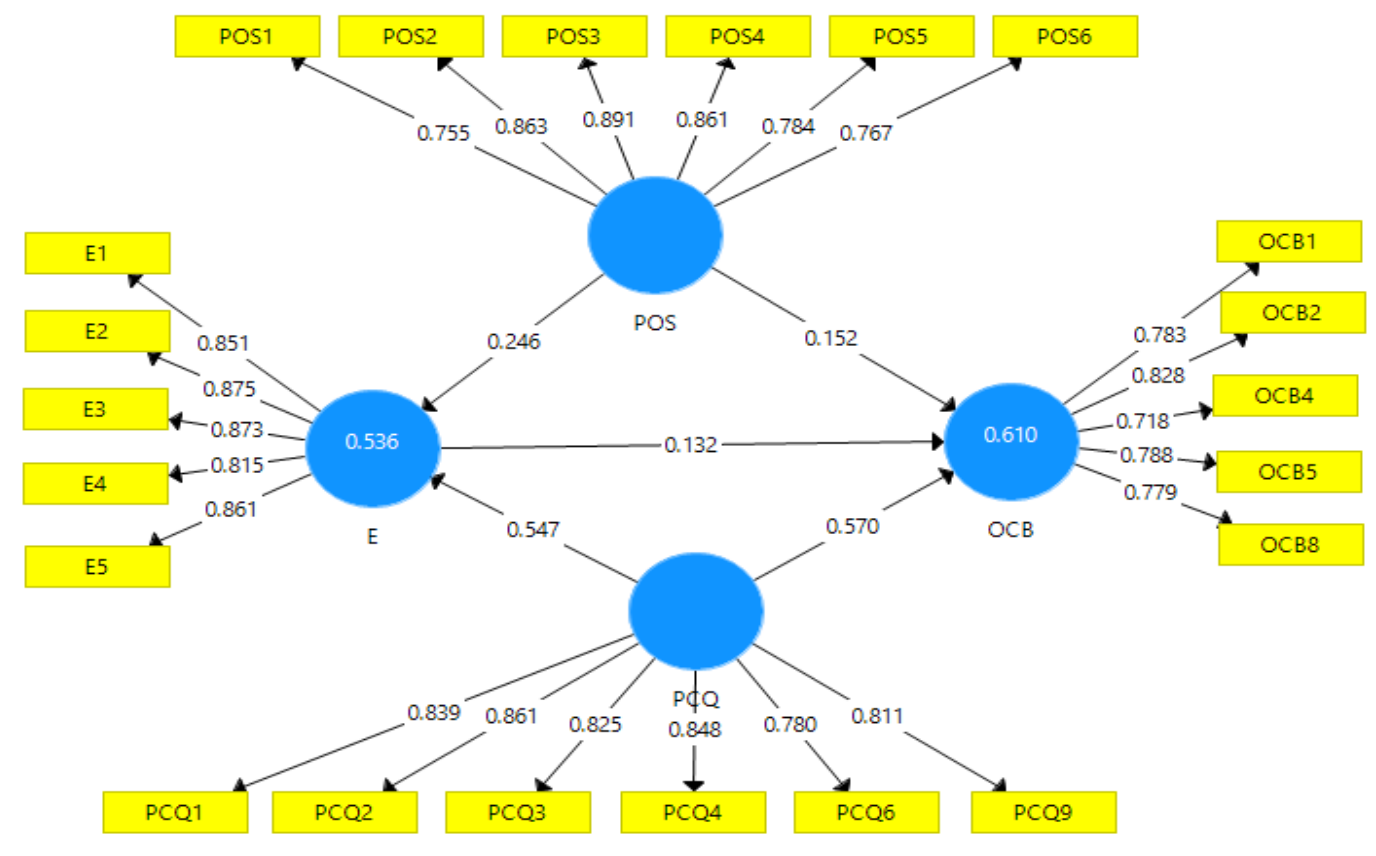

Figure 1.

Result of Path Analysis

that the perception of organizational support has an insignificant on organizational citizenship behavior.The results also supported by the value of the effect size test $\left(f^{2}\right)$ perceived organizational support for OCB of 0.022 which is included in the small category. Therefore, even though the higher support provided by the organization to lecturers, both financial and socio-emotional support, it is not necessarily able to increase lecturers OCB at the Universitas Negeri Semarang.

\section{Psychological capital and OCB}

Based on table 4, the results show that the original sample value $(\beta) 0.209$ and t-statistic value $2.118>1.96$ with a significance value of $0.035<0.05$. This supported $\mathrm{H} 2$ that psychological capital has a positive and significant effect on lecturers OCB at the Universitas Negeri Semarang. This means that the level of psychological capital owned by the lecturer will stimulate them to perform discretionary behavior (eg OCB) in the workplace.

The results of the study supported by relevant literature. For example, Gupta et al. (2017) was found that psychological capital has a positive and significant effect on OCB. Wu \& Nguyen, (2019) also found that psychological capital has a positive and significant effect on work attitudes such as job satisfaction, commitment, and OCB. Positive psychological capital will simultaneously direct lecturers to behave positively in the workplace and will encourage them to engage in extra-role behavior such as OCB which is manifested by helping behavior, provide various ideas for institutional progress, and work with integrity.

\section{Perceived organizational support and work engagement}

Based on table 4, the results show the original sample value $(\beta) 0.000$ and t-statistic value $0.004<1.96$ with a significance value of $0.997>0.05$ so $\mathrm{H} 3$ is rejected that POS has no effect on the level of work engagement of lecturers at the Universitas Negeri Semarang.

Although several previous studies have shown that perceived organizational support has a positive and significant effect on work engagement, for example research by Liu et al. (2017) dan Musenze et al. (2020).

However, in the objects of lecturers, perceived organizational support insignificantly effect on the level of work engagement of lecturers at Universitas 
Table 5.

Specific Indirect Effect

\begin{tabular}{cccccccc}
\hline Hypotheses & \multicolumn{3}{r}{ Relationship } & & $\begin{array}{c}\text { Original } \\
\text { Sample(0) }\end{array}$ & p-value & Description \\
\hline Hypotheses 7 & POS $\rightarrow$ & WE & $\rightarrow$ & OCB & 0.000 & $\mathbf{0 . 9 8 3}$ & Rejected \\
Hypotheses 8 & PsyCap $\rightarrow$ & WE $\rightarrow$ & OCB & 0.097 & $\mathbf{0 . 0 4 9}$ & Supported \\
\hline
\end{tabular}

Negeri Semarang. This study was supported previous research by Yulivianto, (2019) which also found that the perceived organizational support is unable to affect the level of employee work engagement. So, if the organization wants to increase the work engagement of lecturers, the organizational support is not a top priority for them.

\section{Psychological capital and work engagement}

Based on table 4, the results show the original sample value $(\beta) 0.421$ and the $t-$ statistic value $4.573>1.96$ with significance value of $0.000<0.05$. This supported $\mathrm{H} 4$ that psychological capital has a positive and significant effect on the level of work engagement of lecturers at the State University of Semarang.

Empirically the level of lecturers' psychological capital will stimulate them to carry out positive behaviors at work, such as being more intensively engaged in their work. This is supported by previous literature which states that psychological capital can stimulate the level of work engagement. For example, Alessandri et al. (2018) who found that psychological capital was significantly able to predict the level of employee engagement. Kang \& Busser, (2018) who also found that the level of psychological capital owned by employees will have a strong influence on the level of employee engagement. A previous study by Wirawan et al. (2020) explained that the level of work engagement will be stable if employees have sufficient personal resources (psychological capital) to complete the tasks or demands they have.

Based on the analysis, we can speculate that when lecturers are equipped with psychological capital, they will tend to behave more positively at work, for example by being more engaged to their work. The high intensity of lecturer involvement can be realized by the etnthusiastic realized by the enthusiastic attitude of the lecturer in teaching, carrying out his duties, and being fully dedicated to his work.

\section{Work engagement and OCB}

Based on table 4, the results show that the original sample value $(\beta)$ is 0.421 and the $t-$ statistic is $2.400>1.96$ with a significance value of $0.017<0.05$. This supports $\mathrm{H} 5$ that work engagement has a positive and significant effect on lecturers' OCB at Universitas Negeri Semarang.

Empirically, lecturers' work engagement will stimulate them to carry out positive behaviors at work, for example by showing various discretionary behaviors (eg OCB) at work, such as helping co-worker, providing various ideas for the advancement of the institution, working with integrity and prioritizing loyalty to the institution. This is supported by previous literature which states that work engagement can stimulate OCB levels. For example, Srivastava \& Madan, (2016) which proves that employee engagement will have a positive and significant effect on OCB. Saks, (2019) is more comprehensive which proves that work engagement is significantly able to act as a predictor of OCB, both OCBI and OCBO. Choong et al. (2021) which explains that the level of employee work engagement will lead to a significant increase in employee OCB.

\section{Mediating role work engegement on the relationship POS and OCB}

Based on table 5, the results show the original sample value $(\beta)$ of 0.000 and the $t-$ statistic value of $0.021<1.96$ with a significance value of $0.983>0.05$. Therefore, $\mathrm{H} 6$ is rejected that work engagement cannot mediate the positive influence of perceived organizational 
support on lecturers' OCB at Universitas Negeri Semarang.

A previous study by Shams et al. (2020) explained that when employees feel that their contributions are valued and their wellbeing is guaranteed by the organization, employees will offer a positive attitude to their organization and will increase their job roles, which indirectly leads to OCB. However, on the object of lecturers at the Universitas Negeri Semarang, the role of work engagement was not proven to be able to mediate the positive influence between perceptions of organizational support on $\mathrm{OCB}$. That is, in this case work engagement is not able to bridge the relationship between perceptions of organizational support for lecturers' OCB.

The results of this study are also supported by the results of hypothesis 1 which states that POS directly has a positive effect on OCB but insignificant, which is indicated by the t-statistic value of $1.410<$ 1.96 with a significance value of $0.140>$ 0.05 . This means that lecturers' OCB is more likely to be directly improved when the perceived organizational support by the lecturer is high, without the need to feel the lecturer's work engagement. The results are also supported by the results of hypothesis 3 which states that POS has no effect on lecturer work engagement, which is indicated by the t-statistic value of $0.004<$ 1.96 with a significance value of $0.997>$ 0.05 .

\section{Mediating role work engagement on the relationship psycap and $O C B$}

Based on table 5 , the results show the original sample value $(\beta)$ of 0.097 and $t-$ statistics of $1.970>1.96$ with a significance value of $0.049<0.05$ so H7 is accepted that work engagement can mediate the relationship between psychological capital and OCB lecturers at Universitas Negeri Semarang.

The results of this study are supported by previous research which proves that work engagement is able to mediate the relationship between psychological capital and OCB. Gupta et al. (2017) confirmed that employees with high psychological capital will tend to be more committed and involved in their work, where this will indirectly stimulate employees to display discretionary behavior towards the organization, because an employee who is more committed and involved will feel that the work is interesting and will have a responsibility for it. Based on this, it can be conceptualized that the psychological capital owned lecturers will stimulate them to be more committed and involved in their work (teaching, research, service). The high commitment and involvement of the lecturers will make them feel more responsible for their work, which will indirectly influence them to carry out various discretionary behaviors in the workplace. For example, helping coworker, providing various ideas for the advancement of the institution, working with integrity and prioritizing an attitude of loyalty to the institution.

\section{CONCLUSION}

This study aims to examine whether POS and PsyCap will have a direct effect on lecturers' OCB and examine the mediating role of work engagement on the relationship between POS, PsyCap and OCB. The results show that psychological capital has a positive and significant effect on work engagement and OCB, then POS has a positive but not significant effect on OCB and has no effect on work engagement.

The results of specific indirect effect showed that work engagement is able to mediate the relationship between psychological capital and OCB. In addition, psychological capital as an intrinsic factor is considered more capable of influencing lecturers' OCB than POS as an extrinsic factor. So it is highly recommended for organization to start investing in the psychological capital of the lecturers, because the psychological capital of the lecturers will be directly proportional to their positive behavior. In addition, the results also showed that work engagement has a positive and significant effect on OCB. Therefore, it is highly recommended for organizations to constantly monitor the level of work engagement owned by each lecturer. It is important for organization to always ensure that the level of lecturers' work engagement does not fluctuate. Suggestions for organizations to be able to assess and evaluate employee work engagement (especially lecturers) every month by using the Utrecht Work Engagement Scale (UWES) as a measurement scale. 


\section{REFERENCES}

Abdillah, W., \& Hartono, J. (2015). Partial Least Square (PLS) Alternatif Structural Equation Modeling (SEM) dalam Penelitian Bisnis. Penerbit Andi.

Ahmed, I., \& Nawaz, M. M. (2015). Antecedents and outcomes of perceived organizational support: a literature survey approach. Journal of Management Development, 34(7), 867880. https://doi.org/10.1108/JMD-092013-0115

Alessandri, G., Consiglio, C., Luthans, F., \& Borgogni, L. (2018). Testing a dynamic model of the impact of psychological capital on work engagement and job performance. Career Development International, 23(1), 33-47. https://doi.org/10.1108/CDI-11-20160210

Basu, E., Pradhan, R. K., \& Tewari, H. R. (2017). Impact of organizational citizenship behavior on job performance in Indian healthcare industries. International Journal of Productivity and Performance Management, 66(6), 780-796. https://doi.org/10.1108/IJPPM-02-20160048

Bogler, R., \& Somech, A. (2019). Psychological Capital, Team Resources and Organizational Citizenship Behavior. Journal of Psychology: Interdisciplinary and Applied, 153(8), 784-802. https://doi.org/10.1080/00223980.2019. 1614515

Burmeister, A., \& Deller, J. (2016). A practical perspective on repatriate knowledge transfer: The influence of organizational support practices. Journal of Global Mobility, 4(1), 68-87. https://doi.org/10.1108/JGM-09-20150041

Eisenberger, R., Armeli, S., Rexwinkel, B., Lynch, P. D., \& Rhoades, L. (2001). Reciprocation of perceived organizational support. Journal of Applied Psychology, 86(1), 42-51. https://doi.org/10.1037/00219010.86.1.42

Eisenberger, R., Huntington, R., Hutchison, S., \& Sowa, D. (1986). Perceived organizational support. Journal of Applied Psychology, 71(3), 500-507. https://doi.org/10.1037/0021 9010.71.3.500

Fredrickson, B. (2003). The Value of Positive Emotions. American Scientist, 91(4),
330-335

https://doi.org/10.1511/2003.4.330

Frenkel, S. J., \& Bednall, T. (2016). How training and promotion opportunities, career expectations, and two dimensions of organizational justice explain discretionary work effort. Human Performance, 29(1), 16-32. https://doi.org/10.1080/08959285.2015. 1120306

Gouldner, A. W. (1960). The Norm of Reciprocity: A Preliminary Statement. American Sociological Review, 25(2), 161. https://doi.org/10.2307/2092623

Gupta, M., Shaheen, M., \& Reddy, P. K. (2017). Impact of psychological capital on organizational citizenship behavior. Journal of Management Development, 36(7), 973-983. https://doi.org/10.1108/JMD-06-20160084

Hair, J. F., Hult, G. T. M., Ringle, C. M., \& Sarstedt, M. (2016). A Primer on Partial Least Squares Structural Equation Modeling (PLS-SEM) (second). SAGE Publication.

Hall, A. T., \& Ferris, G. R. (2011). Accountability and Extra-Role Behavior. Employee Responsibilities and Rights Journal, 23(2), 131-144. https://doi.org/10.1007/s10672-0109148-9

Han, S.-H., Yoon, D.-Y., Suh, B., Li, B., \& Chae, C. (2019). Organizational support on knowledge sharing: a moderated mediation model of job characteristics and organizational citizenship behavior. Journal of Knowledge Management, 23(4), $\quad$ 687-704. https://doi.org/10.1108/JKM-03-20180213

Huei, T. Y., Mansor, N. N. A., \& Tat, H. H. (2014). Role of OCB and demographic factors in the relationship of motivation and employee performance. Intangible Capital, 10(3), 425-447. https://doi.org/10.3926/ic.435

Indarti, S., Solimun, Fernandes, A. A. R., \& Hakim, W. (2017). The effect of OCB in relationship between personality, organizational commitment and job satisfaction on performance. Journal of Management Development, 36(10), 1283-1293. https://doi.org/10.1108/JMD-11-20160250

Islam, T., \& Ahmed, I. (2018). Mechanism between perceived organizational support and transfer of training: 
Explanatory role of self-efficacy and job satisfaction. Management Research Review, 41(3), 296-313. https://doi.org/10.1108/MRR-02-20170052

Jehanzeb, K. (2020). Does perceived organizational support and employee development influence organizational citizenship behavior?: Personorganization fit as moderator. European Journal of Training and Development, 44(6-7), 637-657. https://doi.org/10.1108/EJTD-02-20200032

Joo, B.-K., \& Lee, I. (2017). Workplace happiness: work engagement, career satisfaction, and subjective well-being. Evidence-Based HRM: A Global Forum for Empirical Scholarship, 5(2), 206221. https://doi.org/10.1108/EBHRM04-2015-0011

Jung, H. S., \& Yoon, H. H. (2015). The impact of employees' positive psychological capital on job satisfaction and organizational citizenship behaviors in the hotel. International Journal of Contemporary Hospitality Management, 27(6), 1135-1156. https://doi.org/10.1108/IJCHM-01-20140019

Kahn, W. A. (1997). Psychological Conditions of Personal Engagement and Disengagement at Work. Academy of Management Journal, 33(4), 692-734. https://doi.org/10.5465/256287

Kang, H. J. (Annette), \& Busser, J. A. (2018). Impact of service climate and psychological capital on employee engagement: The role of organizational hierarchy. International Journal of Hospitality Management, 75(March), 19 https://doi.org/10.1016/j.ijhm.2018.03.0 03

Kataria, A., Garg, P., \& Rastogi, R. (2019). Do high-performance HR practices augment OCBs? The role of psychological climate and work engagement. International Journal of Productivity and Performance Management, 68(6), 1057-1077. https://doi.org/10.1108/IJPPM-02-20180057

Kim, M., \& Beehr, T. A. (2019). The power of empowering leadership: allowing and encouraging followers to take charge of their own jobs. The International Journal of Human Resource Management, 32(9), 1865-1898. https://doi.org/10.1080/09585192.2019. 1657166

Kurtessis, J. N., Eisenberger, R., Ford, M. T., Buffardi, L. C., Stewart, K. A., \& Adis, C. S. (2017). Perceived Organizational Support: A Meta-Analytic Evaluation of Organizational Support Theory. Journal of Management, 43(6), 1854-1884. https://doi.org/10.1177/0149206315575 554

Lee, K., \& Allen, N. J. (2002). Organizational citizenship behavior and workplace deviance: The role of affect and cognitions. Journal of Applied Psychology, 87(1), 131-142. https://doi.org/10.1037/00219010.87.1.131

Liu, J., Cho, S., \& Putra, E. D. (2017). The moderating effect of self-efficacy and gender on work engagement for restaurant employees in the United States. International Journal of Contemporary Hospitality Management, 29(1), 624-642. https://doi.org/10.1108/IJCHM-10-20150539

Liu, M.-S., \& Liu, N.-C. (2021). Impact of human capital strategies on employee attitudes and behavior: a view of internal and external labor markets. International Journal of Manpower, 42(5), 756-776. https://doi.org/10.1108/lJM-06-20190280

Luthans, F., Youssef, C. M., \& Avolio, B. J. (2007). Psychological Capital: Developing the Human Competitive Edge. Oxford University Press. https://doi.org/10.1093/acprof:oso/9780 195187526.001.0001

Morales-Sánchez, R., \& Pasamar, S. (2020). How to improve organisational citizenship behaviour by combining ability, motivation and opportunity: The moderator role of perceived organisational support. Employee Relations, 42(2), 398-416. https://doi.org/10.1108/ER-04-20190169

Musenze, I. A., Mayende, T. S., Wampande, A. J., Kasango, J., \& Emojong, O. R. (2020). Mechanism between perceived organizational support and work engagement: explanatory role of selfefficacy. Journal of Economic and Administrative Sciences, ahead-of$\mathrm{p}$ (ahead-of-print). https://doi.org/10.1108/JEAS-02-20200016

Newman, A., Ucbasaran, D., Zhu, F., Hirst, G. (2014). Psychological capital: A review 
and synthesis. Journal of Organizational Behavior, 35, 120-138. https://doi.org/10.1002/job.1916

Ng, L.-P., Choong, Y.-O., Kuar, L.-S., Tan, C.-E., \& Teoh, S.-Y. (2021). Job satisfaction and organizational citizenship behaviour amongst health professionals: The mediating role of work engagement. International Journal of Healthcare Management, 14(3), 797-804. https://doi.org/10.1080/20479700.2019. 1698850

O'Laughlin, E. M., \& Bischoff, L. G. (2005). Balancing parenthood and academia: Work/family stress as influenced by gender and tenure status. Journal of Family Issues, 26(1), 79-106. https://doi.org/10.1177/0192513X04265 942

Organ, D. W. (1997). Organizational Citizenship Behavior: It's Construct Clean-Up Time. Human Performance, 10(2), 85-97. https://doi.org/10.1207/s15327043hup1 002_2

Park, K. (2019). The Relationship between Power Type, Work Engagement, and Organizational Citizenship Behaviors. International Journal of Environmental Research and Public Health, 16(6), 1015. https://doi.org/10.3390/ijerph16061015

Perreira, T., \& Berta, W. (2015). Increasing OCB: the influence of commitment, organizational support and justice. Strategic HR Review, 14(1/2), 13-21. https://doi.org/10.1108/SHR-01-20150003

Pradhan, R. K., Jena, L. K., \& Bhattacharya, P. (2016). Impact of psychological capital on organizational citizenship behavior: Moderating role of emotional intelligence. Cogent Business \& Management, 3(1), 1194174. https://doi.org/10.1080/23311975.2016. 1194174

Prottas, D. J., \& Nummelin, M. R. (2018). Behavioral Integrity, Engagement, Organizational Citizenship Behavior, and Service Quality in a Healthcare Setting. Journal of Healthcare Management, 63(6), 410-424. https://doi.org/10.1097/JHM-D-1700134

Rego, P., Lopes, M. P., \& Nascimento, J. L. (2016). Authentic leadership and organizational commitment: The mediating role of positive psychological capital. Journal of Industrial Engineering and Management (JIEM), 9(1), 129151. https://doi.org/10.3926/jiem.1540
Saks, A. M. (2006). Antecedents and consequences of employee engagement. Journal of Managerial Psychology, 21(7), 600-619. https://doi.org/10.1108/0268394061069 0169

Saks, A. M. (2019). Antecedents and consequences of employee engagement revisited. Journal of Organizational Effectiveness: People and Performance, 6(1), 19-38. https://doi.org/10.1108/JOEPP-062018-0034

Schaufeli, W., Salanova, M., González-romá, V., \& Bakker, A. (2002). The Measurement of Engagement and Burnout: A Two Sample Confirmatory Factor Analytic Approach. Journal of Happiness Studies, 3(1), 71-92. https://doi.org/10.1023/A:10156309303 26

Seligman, M. E. (2002). Authentic happiness. Simon \& Schuster.

Shams, M. S., Niazi, M. M., \& Asim, F. (2020). The Relationship Between Perceived Organizational Support , Employee Engagement, and Organizational Citizenship Behavior:Application of PLS-SEM approach. Kardan Journal of Economics and Management Sciences, 3(1), https://kardan.edu.af/Research 35-55.

Sia, S. K., \& Duari, P. (2018). Agentic work behaviour and thriving at work: role of decision making authority. Benchmarking, 25(8), 3225-3237. https://doi.org/10.1108/BIJ-07-20170204

Simon, H. A. (1964). On the Concept of Organizational Goal. Administrative Science Quarterly, 9(1), 1. https://doi.org/10.2307/2391519

Srivastava, S., \& Madan, P. (2016). Understanding the Roles of Organizational Identification, Trust and Corporate Ethical Values in Employee Engagement-Organizational

Citizenship Behaviour Relationship: A Study on Indian Managers. Management and Labour Studies, 41(4), 314-330. https://doi.org/10.1177/0258042X16676 675

Tan, L. P., Yap, C. S., Choong, Y. O., Choe, K. L., Rungruang, P., \& Li, Z. (2019). Ethical leadership, perceived organizational support and citizenship behaviors: The moderating role of ethnic dissimilarity. Leadership and Organization Development Journal, 
40(8), 877-897.

https://doi.org/10.1108/LODJ-04-2019-

0160

Tufail, U., Ahmad, M. S., Ramayah, T., Jan, F. A., \& Shah, I. A. (2017). Impact of Islamic Work Ethics on Organisational Citizenship Behaviours among Female Academic Staff: the Mediating Role of Employee Engagement. Applied Research in Quality of Life, 12(3), 693717 . https://doi.org/10.1007/s11482016-9484-5

Wibowo. (2016). Manajemen Kinerja (5th ed.). Rajawali Pers.

Wirawan, H., Jufri, M., \& Saman, A. (2020). The effect of authentic leadership and psychological capital on work engagement: the mediating role of job satisfaction. Leadership \& Organization Development Journal, 41(8), 11391154. https://doi.org/10.1108/LODJ-102019-0433

Wu, W. Y., \& Nguyen, K. V. H. (2019). The antecedents and consequences of psychological capital: a meta-analytic approach. Leadership and Organization Development Journal, 40(4), 435-456. https://doi.org/10.1108/LODJ-06-20180233

Xu, J., Liu, Y., \& Chung, B. (2017). Leader psychological capital and employee work engagement. Leadership \& Organization Development Journal, 38(7), 969-985. https://doi.org/10.1108/LODJ-05-20160126

Yin, N. (2018). The influencing outcomes of job engagement: an interpretation from the social exchange theory. International Journal of Productivity and Performance Management, 67(5), 873-889. https://doi.org/10.1108/IJPPM-03-20170054

Yulivianto, T. S. (2019). Job Crafting Dan Persepsi Dukungan Organisasi Terhadap Kinerja Karyawan Melalui Keterikataerja. Jurnal IImu Manajemen (JIM), 7(4), 1017-1028. https://jurnalmahasiswa.unesa.ac.id/ind ex.php/jim/article/viewFile/29741/27248 